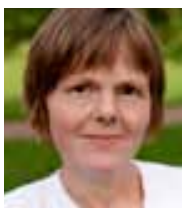

Mai Elin Husebø, sykepleier,

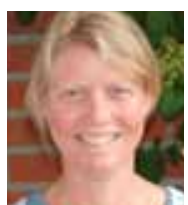

Camilla Fongen,

fysioterapeut, MSC,

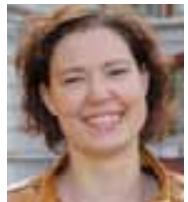

Mari Klokkerud,

ergoterapeut, MSC

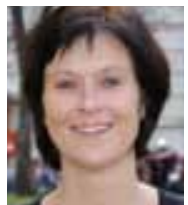

Heidi A. Zangi, sykepleier, PhDstudent.

Alle er ansatt ved Diakonhjemmet sykehus

\title{
Tåler å være fysisk aktive
}

Sykepleiere kan hjelpe pasienter med revmatisk sykdom til økt fysisk aktivitet.

eg kan jo spille bowling med barnebarna mine!» Utsagnet stammer fra en eldre kvinne med vonde knær, rygg og armer. Hun oppdaget at når hun holdt bowlingkula med begge hender og huket seg litt ned med rak rygg så kunne hun også få kula av gårde!

Ved å ha en mulighetsorientert holdning og vilje til dialog med pasienten om muligheter og hindringer kan sykepleiere bidra til økt fysisk aktivitet hos pasienter. En slik holdning er viktig uansett hvilken pasientgruppe man jobber med.

Vi er en tverrfaglig gruppe som består av en sykepleier, fysioterapeut og en ergoterapeut, ved enheten for revmatologisk rehabilitering, Diakonhjemmet sykehus. Fra vinteren 2006 og frem til og desember 2007 prøvde vi ut ulike aktiviteter

\section{« Mange av pasientene hadde få og dårlige erfaringer med fysisk aktivitet.}

www.sykepleien.no

Les mer og finn litteraturhenvisninger på våre nettsider.

\section{Søkeord:}

) Revmatisme

Kronisk sykdom

Fysisk aktivitet

) Mestring

Livskvalitet sammen med pasientene, for eksempel orientering, turgåing, salsa, linedans, padling, bowling, natursti og bordtennis. Erfaringer fra prosjektet har gitt pasienter gode mestringsopplevelser. Det har oppstått en arena for utprøving, lek, vennskapelig konkurranse og latter. Det har bidratt til ideer og inspirasjon. Noen av pasientene har fått sjansen til å gjøre ting de ikke trodde var mulig. Sykepleierne på enheten har gjennom dette prosjektet blitt inspirert til å fokusere ytterligere på fysisk aktivitet og til å tenke muligheter sammen med pasientene. Erfaringene fra aktivitetene har vært et godt utgangspunkt for samtaler om å bruke kroppen; om muligheter og begrensninger.

\section{Bakgrunn}

Fagutviklingsprosjektet hadde sitt utspring på revmatologisk rehabiliteringsenhet, Diakonhjemmet sykehus. Enheten ble åpnet i 2000 og er en del av Nasjonalt revmatologisk rehabiliterings- og kompetansesenter, NRRK. Enheten har landsdekkende funksjon og mottar pasienter med ulike inflammatoriske revmatiske sykdommer og sammensatte problemstillinger til tverrfaglig rehabilitering. I løpet av de fem første årene erfarte vi at mange av pasientene hadde få og dårlige erfaringer med fysisk aktivitet. Vi ønsket å arbeide målrettet mot å fokusere mer på fysisk aktivitet ved vår enhet. Dette er også i tråd med politiske føringer $(1,2)$. Vi bestemte oss for å teste ut et spekter av ulike aktiviteter og tilegne oss kunnskap om hvordan disse aktivitetene kunne tilpasses pasienter med revmatiske sykdommer. Målet var å legge til rette for gode erfaringer med å bruke kroppen, kanskje bryte noen grenser og ikke minst, å ha det moro!

Vi forstår begrepet tilpasset fysisk aktivitet som tiltak som fremmer aktiv, sunn livsstil ved å revurdere psykiske barrierer og motoriske begrensninger ved modifisering, justering eller tillemping i overensstemmelse med individet og omgivelsene (3).

\section{Revmatisme}

Revmatoid artritt, RA, er en sykdom som karakteriseres av kronisk inflammasjon i ledd og som etter hvert fører til leddødeleggelse (5). Inntil for noen år siden har anbefalte treningsformer for personer med revmatisk sykdom vært preget av forsiktighetstankegang. Forskning viser at det store flertallet av pasienter med RA ikke forverrer sin sykdom med økt fysisk aktivitet $(6,7,8)$. Personer med velregulert RA kan stort sett følge treningsanbefalinger som gjelder normalbefolkningen $(5,9)$, men man bør starte trening forsiktig og med mindre belastning enn hos friske.

\section{Metode}

Vi prøvde ut 18 forskjellige aktiviteter og så på mulighetene for å tilpasse dem til personer med forskjellige revmatiske sykdommer og funksjonsnivå. Selve aktiviteten varte i cirka en time hver andre uke. Pasientene og personalet fylte ut et spørreskjema etter endt aktivitet. 116 pasienter svarte. Spørreskjemaet prosjektgruppa fylte ut fokuserte på tilrettelegging og gjennomføring. Sykepleier på kveldsvakt noterte eventuelle spontane reaksjoner eller andre «bivirkninger» som for eksempel smerte i etterkant. De fleste aktivitetene ble prøvd ut flere ganger. Pasientene som deltok hadde ulikt funksjonsnivå. I forkant av hver aktivitet diskuterte sykepleier og de andre i prosjektgruppa sammen med pasientene, behovet for individuelle tilpasninger. 


\section{Pasientenes vurderinger}

84 prosent opplevde aktivitetene som meningsfulle eller veldig meningsfulle (figur 1) og 78 prosent synes aktivitetene var passe vanskelige. 95 prosent svarte at aktiviteten var tilrettelagt slik at de kunne delta. (Se figur 1.)

Stort sett har pasientene opplevd det positivt å gjøre aktivitetene. Det ser også ut til at de har opplevd å mestre aktivitetene bra til tross for at en del har betydelig nedsatt fysisk funksjon. En ung kvinne som var sterkt preget av aktiv artrittsykdom og

\section{« Man må våge å utfordre grenser.}

kortisonbehandling, fikk prøve seg på sjøen i en stabil kajakk. Med en kort, lett padleåre klarte hun å manøvrere kajakken inne på grunna. I ettertid har hun gitt uttrykk for glede og stolthet over padleturen og ikke minst det at hun faktisk torde å sette seg i båten. (Se figur 2.)

90 prosent svarte at de kunne tenke seg å gjenta aktiviteten. 63 prosent trodde det ville være mulig å gjøre aktiviteten på hjemstedet (figur 2). For eksempel var det en eldre dame med RA som gledesstrålende oppdaget at bowling var en aktivitet hun kunne gjøre sammen med barnebarna sine. Et annet eksempel var en ung jente med RA som ikke likte noen former for sport. Hun fant likevel ut at bordtennis var morsomt og kunne være noe for henne.

\section{Personalets erfaringer}

Personalets viktigste erfaringer var:
, Man må våge å utfordre grenser

, Det skal ofte små og enkle justeringer til for å tilpasse aktiviteter til den enkeltes behov

, Behov for god planlegging, kjennskap til aktiviteten og kjennskap til pasientene.

\section{Å utfordre grenser}

Å våge å utfordre grenser gjelder i like stor grad for personalet som for pasientene. Vi opplevde at vi ble utfordret mer enn en gang av våre egne forestillinger om hva som var pasientenes begrensninger. Både personalet og pasientene ble overrasket over hva som er mulig å få til ved god tilrettelegging og at man tør å prøve.

Det skal ofte små og enkle justeringer til for å tilpasse aktiviteter til den enkeltes behov. Bowling er kanskje ikke den aktiviteten man først tenker på som passende for en person med smertefulle eller deformerte fingre. Men han eller hun kan kanskje delta ved å bruke en av de letteste kulene og holde den i begge hender. Hvis det er for vondt eller tungt, kan man få hjelp til å plassere kula på et stativ, og deretter dytte den av gårde. Stativ er tilgjengelig i bowlinghallen ved henvendelse til personalet. Slike enkle tilpasninger kan gjøre det mulig å delta, men det er viktig at justeringene føles akseptable.

\section{Kjennskap til pasientene}

For at aktivitetene skal bli mest mulig vellykket, er det viktig å ha tenkt gjennom hva slags tilpasningsmuligheter man har i forhold til den aktiviteten som skal prøves ut. Dette må ses i sammenheng med pasientenes funksjonsnivå og forutsetter at man har et visst kjennskap til pasientene. Det er viktig å involvere pasientene i
FIGUR 1: Opplevelse av meningsfullhet i de ulike aktivitetene.

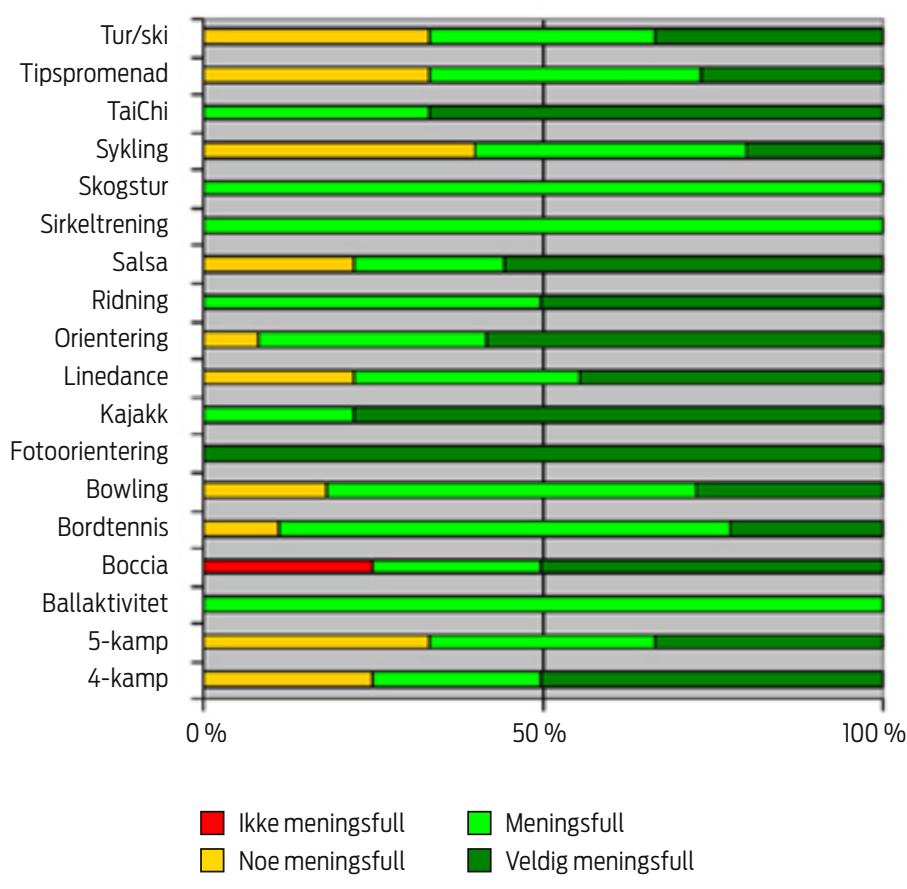

FIGUR 2: Hvorvidt er det mulig å gjøre aktiviteten på hjemstedet?

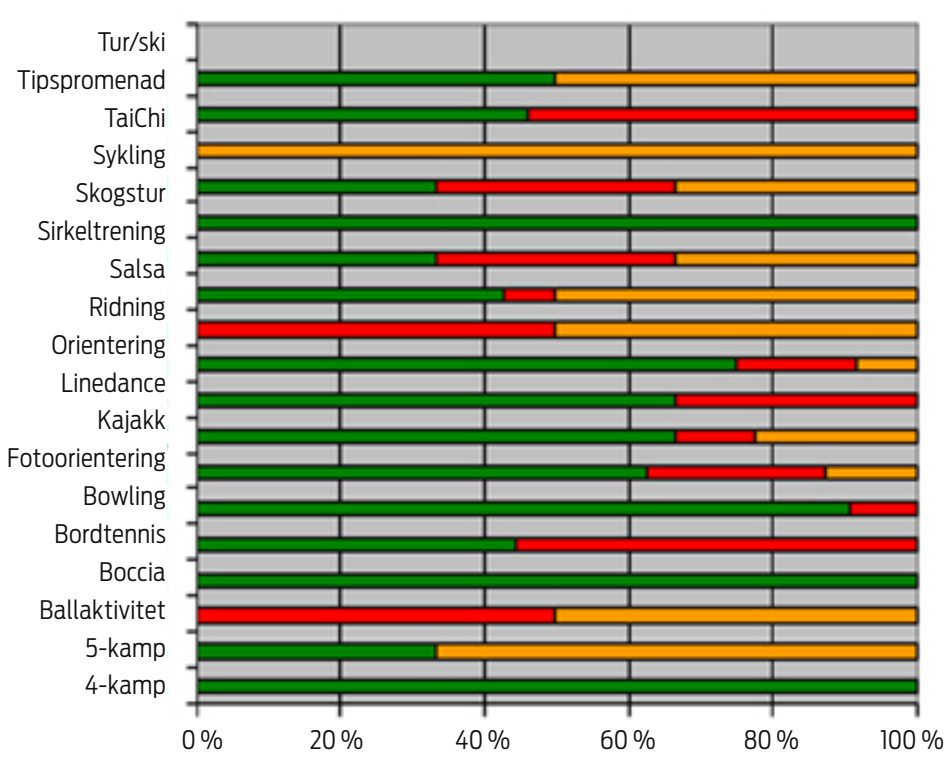


forkant av aktiviteten. Da er pasienten forberedt og kan bidra med innspill om tilrettelegging og komme med eventuelle behov. Det er i planleggingsfasen man diskuterer hvordan det er mulig å overkomme eventuelle psykiske og fysiske barrierer for å delta i aktiviteten. Sykepleieren og de andre faggruppene har sammen med pasienten mulighet til å komme med verdifulle innspill.

\section{Aktivitet gir helse}

Som resten av befolkningen, er pasienter med revmatiske sykdommer utsatt for livsstilssykdommer som følge av inaktivitet. Helsedirektoratets generelle anbefalinger for voksne er $30 \mathrm{mi}-$ nutters moderat intensiv aktivitet per dag. Vi vet at dette gir stor helsegevinst (4). Det er ingen grunn til å tro at disse anbefalingene ikke også gjelder personer med revmatisk eller annen kronisk sykdom. Som sykepleier kan jeg initiere samtaler med pasienter om fysisk aktivitet, og det kan være aktuelt å stille spørsmål om på hvilken måte de er fysisk aktive, hvor ofte, hva de liker å gjøre og hva slags erfaringer de har. Tror de fysisk aktivitet er bra for dem med de plagene de har? Er de usikre på hva de kan gjøre? Her kan sykepleierne bidra med kunnskap om sykdom og fysisk aktivitet.

\section{Oppsummering}

Erfaringene fra fagutviklingsprosjektet viste oss at begrensninger for fysisk aktivitet kan være av psykisk og fysisk art, og både pasientene og personalet må våge å utfordre egne grenser. Vi fant ut at det er mulig å gjennomføre aktiviteter ved hjelp av god planlegging og tilrettelegging.

Artikkelen er en del av Mai Elin Husebøs fordypningsoppgave i forbindelse med videreutdanning i revmatologisk sykepleie ved Høyskolen i Bergen, kull 2007.1

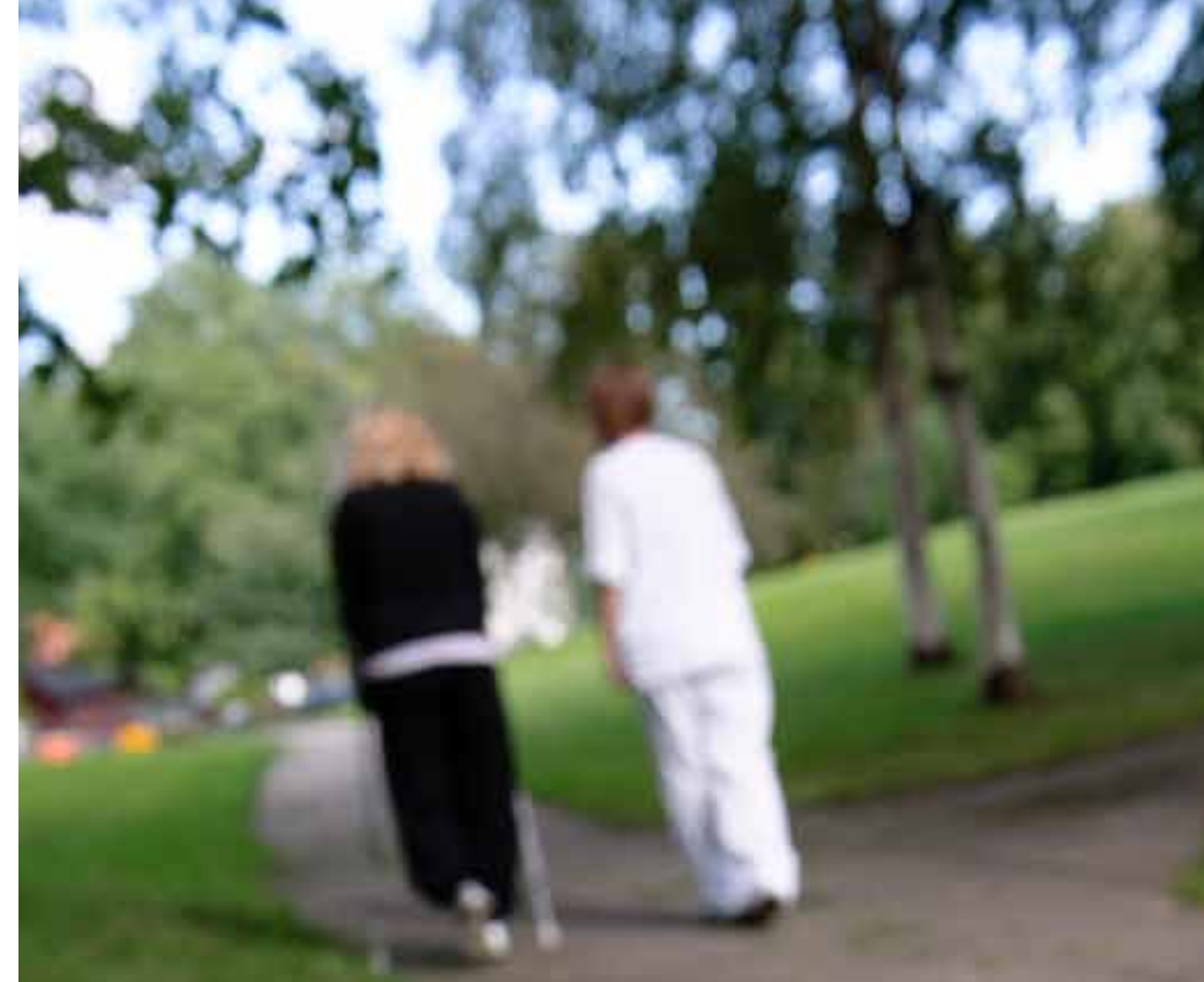

\section{LITTERATUR}

Resept for et sunnere Norge. Folkehelsepolitikken. St. melding nr. 16 (2002-2003). Det kongelige helsedepartement; 2002.

2. Sosial og Helsedirektoratet. Sammen for fysisk aktivitet. Handlingsplan for fysisk aktivite 2005-2009. 2005.

3. Sherrill C. Adapted Physical Activity, Recreation and Sport: Crossdisciplinary and Lifespan. 5. utg. WCB/Mc Graw-Hill: 1998.

4. Bedrehelse på 1-2-30 [internett]. Helse og omsorgsdepartementet Arbeids og inkluderingsdepartementet, Barn og likestillingsdepartementet,Kommunal og regionaldepartementet Kultur- og kirkedepartementet, Miljøverndepartementet, og Kunnskapsdepartementet. [hentet 22. september 2008] Titgjengelig fra: http://www.l-2-30. no/bedrehelse/helsegevinster/

5. Klareskog L, Saxne T, Enman Y red. Revmatologi. 1.utg. Studentlitteratur; 2005

6. M, Hazes JM. Dynamic exercise therapy for rheumatoid arthritis. Cochrane Database Syst Rev 2000; CD000322

Ophava CH, Nisell R. Reumatoid artrit. I: Ståhle A. red. Fyss 2008 Yrkesföreningar för fysisk aktivitet; 2008. s.504-514.

8. De Jong Z, Vliet Vlieland TPM. Safety of exercise in patients with rheumatoid arthritis. Curr. Opin. Rheumatol. 2005; 17(2): 177-82

9. Stålhe A. red. Fyss 2008. 1.utg. Stockholm: Yrkesföreningar för fysisk aktivitet; 2008.

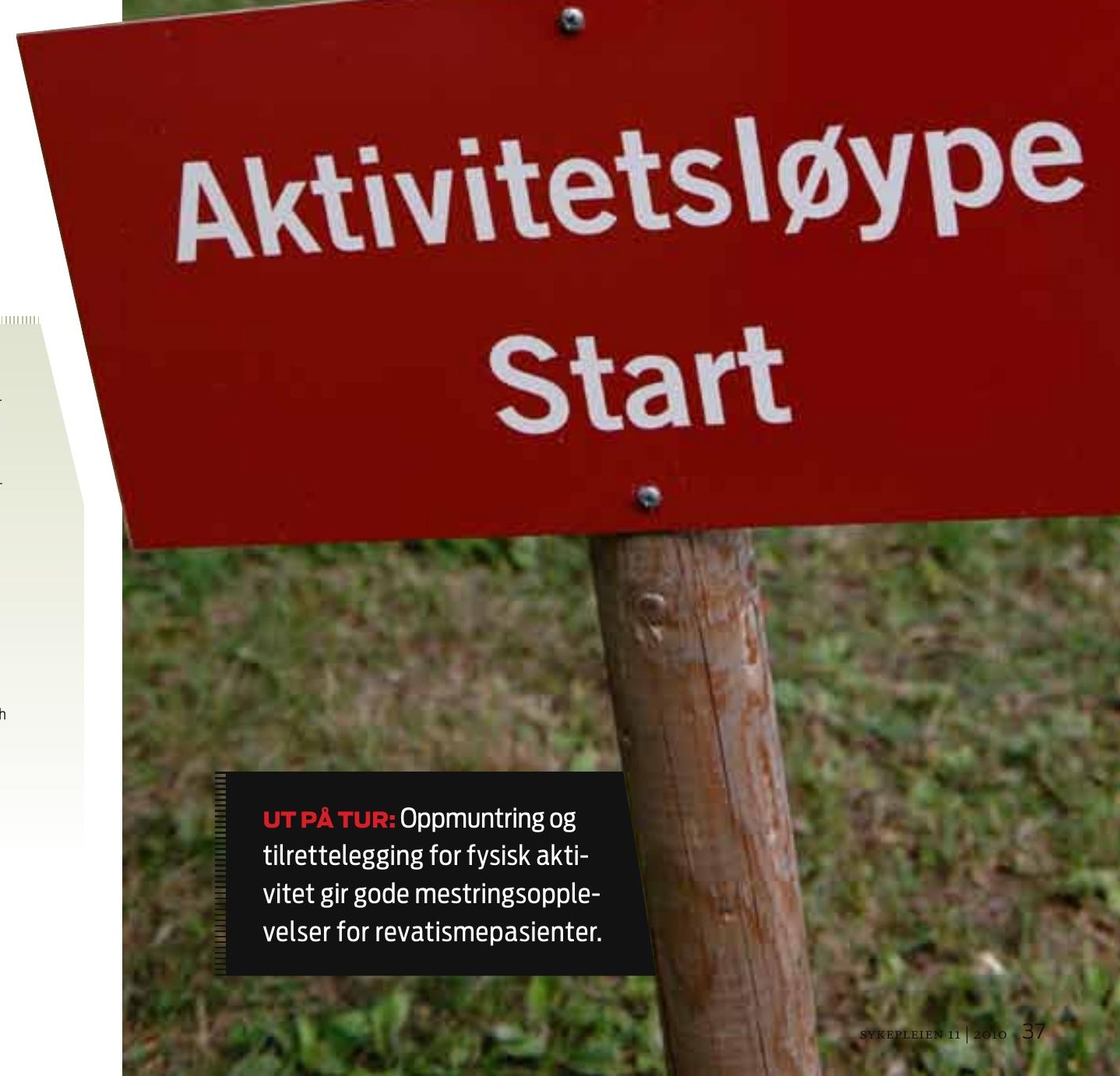




\section{Fortviler over lang ventetid}

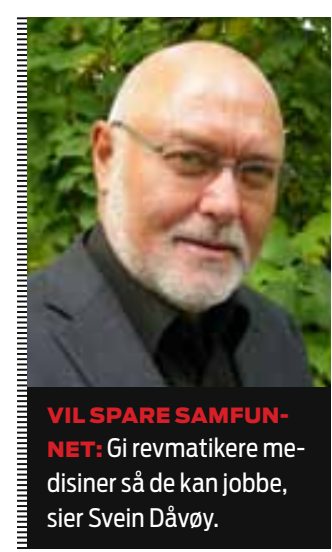

Pasienter med leddsmerter må vente på behandling.

Mange får ødelagt ledd mens de står i kø. Det kunne vært unngått.

Tekst Nina Hernæs

$\mathbf{R}$ evmatikerforbundets leder har mest lyst til å gråte. Svein Dåvøy vet at nye behandlingsmetoder kan bremse sykdomsprosessen og hindre at ledd blir ødelagt.

- Får revmatisk sykdom utvikle seg, skades leddene, sier Dåvøy. For ikke å snakke om enkelte diagnoser, som lupus, der indre organer blir ødelagt.

- Og er skaden skjedd, er den irreversibel.

\section{Liten forståelse}

Derfor er han opptatt av tidlig diagnose og behandling. Men han mener det er systemsvikt i helsevesenets prioriteringer.

- Fastlegene henviser for sent til revmatolog. Revmatologene er for få og for restriktive med medisiner og behandling. Sykehusene styrer etter gitte budsjettrammer, og myndighetene klarer ikke å se utgiftene til helse og trygd i sammenheng, mener Dåvøy.

- Pasienter med revmatiske sykdommer blir ikke friske, men blir sykdommen hindret i å utvikle seg, kan mange leve tilnærmet normale liv og være i jobb. Det er enorme summer å spare på at vi med revmatiske sykdommer deltar i samfunnet og ikke ender på uføretrygd.

\section{Har vondt}

- Både medisiner, fysioterapi og tilrettelegging kan forhindre lidelse og nedsatt funksjonsevne. Men det krever at pasientene kommer raskt til behandling.

Dåvøy, som fikk Bechterev i tjueårsalderen, ventet åtte år på diagnose. Hele tiden hadde han sterke smerter.

Diagnosen på revmatisk sykdom kan være vanskelig å stille. Hos mange pasienter er smerter det dominerende symptomet. Dåvøy beskriver smertene som alltid å ha tannverk. Han ønsker at fastleger skal bli mer oppmerksomme på smerte og ta den på alvor.

- Smerte er subjektivt og måles ikke. Derfor blir den svært ofte bagatellisert av medisinerne, sier han.

Før var holdningen at behandlingen fikk vente til revmatismen var synlig på røntgen.

- Den tenkningen har vært en katastrofe for pasientene.

\section{Vil samarbeide}

Dåvøy peker på at det er rundt 300000 nordmenn med revmatisme. Å begrense sykdomsutviklingen vil føre til færre sykehusinnleggelser, mindre sykefravær, mindre utgifter til trygd, pleie og omsorg.

Et problem er at de nye biologiske medisinene er kostbare. Prisen for en pasient kan komme opp i over 100000 kroner i året. Men Dåvøy har ingen forståelse for at utgiftene er et argument mot behandling.

- Sykehusene er bedrifter og har som mål å holde budsjettet. Når rammene er for små til å behandle alle, flyttes kronikere bakover i køen. Konsekvensen er at mange kommer for sent til behandling, og dermed skyves de ufrivillig over på trygd. Samfunnsøkonomisk er dette forkastelig. På sikt kunne vi spart enorme beløp dersom flere kunne arbeidet. Myndighetene må være blinde som ikke ser det, sier han.

Dåvøys agenda er å bidra til at behandlingstilbudet blir bedre.

- Vi har innledet samarbeid med revmatologer og allmennleger. Vi ønsker å øke kunnskapen om revmatisme, blant annet på medisinstudiet. Og vi vil veldig gjerne ha politikerne i tale. De snakker om å få ned sykefraværet. Gjør de noe for å bedre behandlingen av revmatisme, er det et tiltak som virkelig vil monne.

\section{For få vil videreutdanne seg}

Høgskolen i Bergen tilbyr videreutdanning i revmatologisk sykepleie. To kull er uteksaminert. Et nytt kull skulle startet i høst, men få søkere har ført til at studiestart er avlyst. Utdanningen er på deltid, varer i halvannet år og gir 60 studiepoeng.
- Sykepleierne strever med å få arbeidsgiverne til å betale, erfarer høyskolelektor Kari Miljeteig.

Hun har fagansvaret for videreutdanningen.

- Det har skjedd en endring de siste to-tre årene, og det stiller jeg meg undrende til, sier hun.
- Jeg kan ikke skjønne annet enn at det er behov for mer kompetanse om revmatisme.

Høgskolen i Bergen har ingen konkrete planer, men Miljeteig håper å kunne tilby videreutdanningen igjen. 
Hva er utfordringene

for revmatologisk sykepleie?

\section{Frykter for faget}

\section{- Pasienter med revmatisme trenger syke- pleiere med kompetanse, mener faggruppen. De frykter nedleggelse og sammenslåing.}

Tekst Nina Hernæs

$\mathbf{M}$ indre behov for sengeplasser har ført til færre rene revmatologiske sengeposter. I stedet slås ulike fagfelt sammen og samles i en felles post. For eksempel kan noen senger på en avdeling øremerkes til revmatologi. Det frykter leder for revmatismesykepleierne, Merethe Beate Norum, vil føre til dårligere sykepleie.

- Å gi god sykepleie til disse pasientene krever kunnskap og erfaring, sier hun.

Hun frykter fagfeltet vil drukne i sammenslåinger.

- For revmatikere er det en utfordring at sykdommen ikke syns. De kan virke mindre syke enn de med slag eller andre synlige sykdommer, og dermed ikke bli prioritert i en hektisk hverdag.

\section{Jobber med det de kan}

Norum peker på hvor viktig det er å sette seg inn i hvordan revmatikere har det.

- Vi er redde for at pasientene ikke skal bli forstått, sier hun.

Hun mener det er viktig å bevare og stimulere kompetansen til revmatologiske sykepleiere. Flere av dem er spesialsykepleiere.

- Sykepleierne bør få jobbe med det de er best på, ikke spres på mange ulike sykdommer, sier hun.

- Og pasientene som kommer til spesialisthelsetjenesten bør møte sykepleiere som er gode på sitt fagfelt, poengterer hun.

\section{Utvikler fag}

Norum har jobbet 20 år med revmatologi. Nå er hun på sengepost. Det er ikke en ren revmatologisk post, men hun er opptatt av å få til en turnus hvor revmatologiske sykepleiere fortsatt får jobbe med revmatisme.

Rundt 230 sykepleier er medlem av faggruppen. En viktig oppgave er å drive fagutvikling.

- Vi har seminarer, deler ut stipender og holder nettsiden vår oppdatert, forteller Norum.

- Fagfeltet har endret seg og det har også sykepleierrollen. Vi jobber mye mer selvstendig enn før. IIII

\section{Les om legemidler}

På nettet fins en egen side med pasientrettet informasjon om legemidler mot revmatisme.

Norsk Revmatologisk Forening, Norske Sykehusfarmasøyters Forening, Norsk Revmatikerforbund og Norsk Psoriasisforbund står bak. Les mer på www.legeforeningen.no/id/94693.0

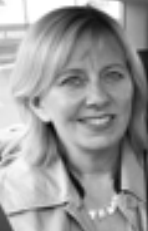

Kim Hellesnes Revold, sykepleier ved revmatologisk poliklinikk, Universitetssykehuset i Nord-Norge:

At vi ikke blir generalister. Det er en fare for at spesialkompetansen hos revmatologiske sykepleiere forsvinner når det ikke lenger er egne sengeposter. Sykepleierkompetansen må inkluderes i poliklinikkene. Det må sykehusene være oppmerksomme på når de utvikler driften fra sengepost til dagbehandling. Også sykepleiere skal ha spesialkompetanse.

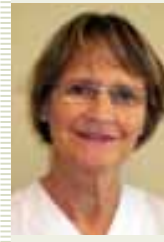

Vigdis Utgaard, sykepleier ved revmatologisk poliklinikk, St. Olavs Hospital: Å være faglig oppdatert. Det forskes mye på revmatisme og utvikles stadig nye medisiner. Mange pasienter følger med på utviklingen og stiller spørsmål. Informasjon er en viktig del av sykepleien og pasientene forventer at vi kan gi råd.

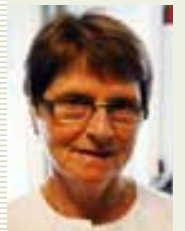

- Eldfrid Flataker, avdelingssykepleier ved revmatologisk poliklinikk, Haukeland universitetssykehus:

Å få tid til å følge opp de som starter med nye medisiner og som har behov for veiledning.

Det er legene som tar hånd om behandlingen, men vi står for opplæringen når medisinen for eksempel skal settes subkutant. Det medfører også en del forarbeid.

Vi prøver også å ringe dem etterpå for å høre hvordan det går hjemme.

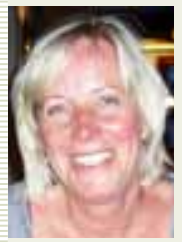

Solfrid Jaatun, avdelingssykepleier, revmatologisk avdeling, Sørlandet sykehus: Det har skjedd stor utvikling innenfor behandlingen, og det skaper nye problemstillinger. Pasientene har kanskje større forventninger til hva behandlingen kan utrette. De har lett tilgang på informasjon og kan mye mer enn tidligere. Det skaper større forventninger til sykepleierne.

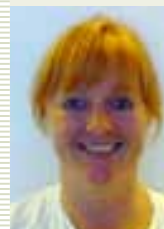

Karen Elise Lindøe, spesialsykepleier, Haugesund Sanitetsforenings Revmatismesykehus:

At faget i større grad går over til å være et poliklinisk fag. Det medfører andre arbeidsoppgaver, måter og jobbe på og ikke minst mer ansvar i oppfølging av pasienter. 